\title{
Lifrarskaði tengdur notkun á Herbalife
}

Magnús Jóhannsson læknir, prófessor í lyfjafræði

\section{Sif Ormarsdóttir}

meltingarlæknir ${ }^{2}$

Sigurður Ólafsson

meltingarlæknir ${ }^{3}$

Lykilorð: eitrunarlifrarbólga, náttúruefni, Herbalife.

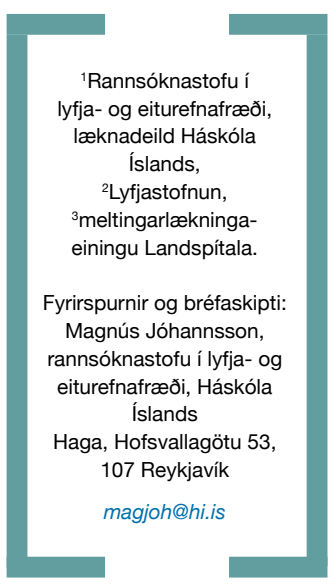

\section{Ágrip}

Tilgangur: Mörg náttúruefni eru pekkt að pví að geta valdið lifrarskaða. Nýleg íslensk könnun á aukaverkunum náttúruefna sýndi að lifrarskaði var oftast tengdur notkun Herbalife.

Aðferðir: Lýst er fimm tilfellum af eitrunarlifrarbólgu í tengslum við notkun á ýmsum Herbalifevörum á Íslandi á árunum 1999 til 2008. Orsakatengsl voru metin með skilmerkjum WHOUMC en einnig með RUCAM aðferðinni.

Niðurstöður: Af fimm sjúklingum voru fjórar konur og einn karl. Miðgildi aldurs var 46 ár (spönn 29-78 ár). Lengd Herbalifenotkunar var á bilinu 1-7 mánuðir. Fjórir sjúklinganna voru með klíníska mynd lifrarfrumuskaða en einn með gallstíflulifrarskaða. Miðgildi fyrir eftirfarandi voru: bílirúbín $190 \mu \mathrm{mol} / \mathrm{L}$ (spönn: 26-311; eðlilegt <20 $\mu \mathrm{mol} / \mathrm{L})$, ALP $407 \mathrm{U} / \mathrm{L}$ (spönn: 149-712; eðl. 35-105 U/L) og ALT 2487 U/L (spönn: 456-2637; eðl. 70 og $45 \mathrm{U} / \mathrm{L}$ fyrir karla og konur). Lifrarástunga var gerð í tveimur sjúklinganna og samrýmdust vefjabreytingar eitrunarlifrarbólgu. Aðrar orsakir lifrarbólgu voru útilokaðar með viðeigandi mótefnaprófum og ómskoðun. Orsakatengsl voru samkvæmt RUCAM-aðferðinni líkleg í premur og möguleg 1 tveimur en samkvæmt skilmerkjum WHO örugg 1 einu tilfelli, líkleg í tveimur og möguleg í tveimur. Ályktanir: Telja verður líklegt að notkun á Herbalifevörum tengist eitrunarlifrarbólgu. Eitrunarlifrarbólga af völdum náttúruefna er mikilvæg mismunagreining hjá sjúklingum með lifrarskaða.

\section{Inngangur}

Eitt algengasta alvarlega vandamálið við lyfjanotkun er eitrunarlifrarbólga (toxic hepatitis) og á undanförnum áratugum hafa allmörg lyf horfið af sjónarsviðinu vegna pessa vandamáls. Mörg önnur lyf eru notuð með varúð vegna aukaverkana á lifur. Mörg peirra lyfja sem eru á markaði eru fengin úr náttúrunni og sum peirra geta valdið eitrunarlifrarbólgu. Telja verður að læknar séu almennt vel meðvitaðir um pessi vandamál.
Orðið náttúruefni er hér notað um öll efni úr náttúrunni sem ekki eru lyf (náttúrulyf, náttúruvörur, fæðubótarefni) og ætluð eru til að bæta heilsufar eða útlit. Notkun slíkra efna hefur farið vaxandi á undanförnum árum víða um heim og á pað sér örugglega margar skýringar. Ein ástæðan er talin vera trú margra á pví að efni úr náttúrunni séu laus við aukaverkanir og virðist sú skoðun lífseig prátt fyrir vísindalega vitneskju um hið gagnstæða. ${ }^{1}$

Eitruð efni eru mjög algeng í náttúrunni, meðal annars í jurtum. Talið er að pessi efni pjóni ákveðnum tilgangi við að verja jurtina (lífveruna) fyrir utanaðkomandi árásum, til dæmis skordýra og grasbíta. Efnin verja jurtina á mismunandi hátt, pau geta meðal annars verið bragðsterk eða eitruð. Sterkt bragð fælir frá grasbíta og jafnvel önnur dýr og eitruð efni fæla líka frá með pví móti að dýrin læra af reynslunni að viðkomandi jurt er eitruð. Eiturverkanir náttúruefna eru mjög margvíslegar en algengar eru eiturverkanir á meltingarfæri, nýru, húð og lifur.

Efni sem eru eitruð fyrir lifrina eru algeng í náttúrunni. ${ }^{2}, 3$ Lifrarvandamál við notkun náttúruefna í fæðubótarefnum eru vel pekkt en ekki er vitað hve stórt petta vandamál er.

Eitruð náttúruefni geta valdið margvíslegum lifrarskaða svo sem bráðri eða langvinnri lifrarbólgu, gallstíflu, æðaskemmdum og jafnvel lifrarbilun og skorpulifur. Mikill fjöldi jurta inniheldur efni sem geta valdið eitrunarlifrarbólgu og má par nefna sem dæmi Kava, Ma-huang (inniheldur efedrín), Aloe vera til inntöku ${ }^{4}$ og grænt te (Camellia sinensis). ${ }^{5-7}$ Af íslenskum jurtum má nefna krossfífil (Senecio vulgaris) og hóffífil (Tussilago farfara) sem báðir innihalda eitraða pýrróla (pyrrólizidín plöntubasa). ${ }^{3,8,9}$

Veturinn 2002-03 var gerð könnun meðal íslenskra lækna á aukaverkunum náttúruefna og voru niðurstöðurnar birtar í Læknablaðinu. ${ }^{10}$ Í pessari rannsókn skáru vörur frá Herbalife sig úr varðandi lifrarvandamál. Flestar tilkynningar bárust um Herbalife eða alls 78 og voru 12 peirra um lifrarvandamál og flokkuðust pau öll sem alvarleg (sjúkrahúsvist). Næstflestar tilkynningar 
Tafla I. Taflan sýnir hvađa vörur frá Herbalife sjúklingarnir voru að nota. Í sumum tilfellum var um fleiri vörur að ræða en hér eru nefndar.

\begin{tabular}{lccccc}
\hline \multicolumn{1}{c}{ Nafn vöru } & \multicolumn{5}{c}{ sjúkl. } \\
\hline & 1 & 2 & 3 & 4 & 5 \\
\hline Rose Ox & $\mathrm{x}$ & $\mathrm{x}$ & $\mathrm{x}$ & $\mathrm{x}$ & $\mathrm{x}$ \\
\hline Florafibre & $\mathrm{x}$ & & $\mathrm{x}$ & & \\
\hline Thermojetics & $\mathrm{x}$ & $\mathrm{x}$ & & $\mathrm{x}$ & \\
\hline Fiber- och örttabletter & & $\mathrm{x}$ & & & \\
\hline Herbalifeline & & & $\mathrm{x}$ & $\mathrm{x}$ \\
\hline Tang Kuei & & $\mathrm{x}$ & & \\
\hline
\end{tabular}

bárust um ginseng eða alls 47 en engin peirra var vegna lifrarvandamála. Ein tilkynning var um gulu vegna sólhatts. Vegna eðlis pessarar rannsóknar var ekki hægt að útiloka að eitthvað af pessum tilfellum væru talin oftar en einu sinni og ekki fengust upplýsingar um hvaða vörutegundir frá Herbalife pessir einstaklingar höfðu tekið. Pessar niðurstöður voru túlkaðar sem merki um hugsanlega hættu sem pyrfti að kanna betur.

\section{Efniviður og aðferöir}

Pessi samantekt nær til tilfella sem höfundar höfðu vitneskju um á árunum 1999-2008. Ekki var gerð skipulögð leit að sjúklingum með lifrarskaða tengdan náttúruvörum. Farið var yfir sjúkraskýrslur og kannaðar upplýsingar um heilsufar, töku lyfja og töku náttúruefna. Sérstaklega var reynt að afla upplýsinga um hvaða vörur frá Herbalife pessir einstaklingar höfðu notað. Við uppvinnslu sjúklinganna höfðu að jafnaði verið gerðar eftirfarandi rannsóknir til útilokunar á öðrum lifrarsjúkdómum: Blóðvatnspróf fyrir lifrarbólguveirum A, B og C, cýtómegalóveiru og Ebstein Barr veiru; sjálfsnæmispróf með tilliti til lifrarbólgu (kjarnamótefni [ANA], sléttvöðvamótefni [SMA] og orkukornamótefni [AMA]); ómskoðun af lifur og gallvegum; lifrarástunga var gerð í völdum tilfellum.

Við mat á orsakatengslum var notast við Roussel Uclaf Causality Assessment Method (RUCAM) aðferðina ${ }^{11}$ en einnig var stuðst við skilmerki WHO - UMC varðandi orsakatengsl. ${ }^{12}$ RUCAM-aðferðin er sérstaklega hönnuð með lifrarskaða af völdum lyfja í huga. RUCAMmatið tekur pannig til greina tímasamband en einnig aðra áhættupætti fyrir lifrarskaða, sem og hvort aðrir lifrarsjúkdómar hafi verið útilokaðir. Gefin eru stig fyrir ýmsa undirpætti í spurningalista og er lokaniðurstaða pannig að pví fleiri stig pví meiri líkur á orsakasambandi.
Eftir stigafjölda er svo orsakasambandið metið allt frá útilokað til mjög líklegt. WHO-aðferðin metur samband lyfja og aukaverkana almennt og tekur mið af tímasambandi milli inntöku og einkenna, öðrum hugsanlegum skýringum og hvort endurinntaka síðar leiddi til sömu sjúkdómseinkenna. Niðurstaðan er gefin sem lýsingarorð frá ósennilegt yfir í öruggt.

Fengin voru tilskilin leyfi Persónuverndar og Vísindasiðanefndar og auk pess leyfi yfirmanna á Landspítala og í Háskóla Íslands.

\section{Niðurstöður}

Tilfelli 1:

46 ára gömul heilsuhraust kona var lögð inn á Landspítala eftir 10 daga ógleði, slappleika og vaxandi gulu. Hún hafði notað Herbalifevörur í rúman mánuð en engin lyf. Fyrir utan hækkun á lifrarprófum, leiddu blóðrannsóknir í ljós hækkun á kjarnamótefnum (ANA, títri $>1: 300$ ). Orkukornamótefni (anti-mitochondrial antibodies; AMA) voru jákvæð við komu í títra 1:160 og hækkuðu innan mánaðar í 1:320. Próteinrafdráttur sýndi fjölklóna IgG hækkun (19,1 g/L). Í lifrarsýni sáust merki um bráða lifrarbólgu með áberandi blandaðri bólgufrumuíferð á portalsvæðum en einnig utan peirra. Plasmafrumur voru áberandi en einnig eitilfrumur, daufkyrningar og rauðkyrningar sáust einnig. Talsverð gallstífla í smáum gallgöngum (hepatocanalicular). Útlit talið samrýmast best lyfja- eða eitrunaráhrifum en ekki var hægt að útiloka aðrar orsakir, svo sem lifrarbólgu vegna sjálfsnæmis. Konan hætti töku Herbalife og lifrargildi lækkuðu hratt og var ALAT 84 innan mánaðar. Konan var ekki meðhöndluð með prednisólon eða öðrum lyfjum. Tæpu ári síðar var ANA veikt jákvætt (<1:40), AMA títri 1:160 en lifrarpróf alveg eðlileg.

\section{Tilfelli 2:}

47 ára gömul kona var lögð inn eftir að hafa verið um tveggja vikna skeið með gulu og kláða. Hún hafði áður verið með háprýsting og vanstarfsemi í skjaldkirtli og ári ádur með gulu vegna Primazol (trímetóprím og súlfametoxasól). Lyf: Atenólól og týroxín (langtímanotkun). Hafði notað bæði Herbalife og sólhatt (echinacea) en óljóst hversu lengi. Rannsóknir voru allar neikvæðar með tilliti til annarra lifrarsjúkdóma. Hún hætti töku fæðubótarefna og innan priggja mánaða voru lifrarpróf orðin eðlileg. Hún hætti einnig notkun atenólóls tímabundið en hóf síðar töku pess aftur. Lifrarpróf héldust eðlileg. 
Tafla II. Yfirlit yfir sjúklingana, tegund lifrarskaða og orsakatengsl vöru og lifrarskaða samkvæmt skilmerkjum WHO og RUCAM.

\begin{tabular}{ccccccccccc}
\hline sjúkl. nr. & kyn & aldur (ár) & biðtími (mán.) & $\begin{array}{c}\text { tegund } \\
\text { skemmdar }\end{array}$ & $\begin{array}{c}\text { vefsýni } \\
\text { endurgjöf }\end{array}$ & $\begin{array}{c}\text { orsakatengsl } \\
\text { vöru }\end{array}$ & $\begin{array}{c}\text { orsakatengsl } \\
\text { (WHO) }\end{array}$ \\
\hline 1 & kvk & 46 & 1 & HC & já & nei & líkleg & líkleg \\
\hline 2 & kvk & 47 & $?$ & HC & nei & nei & möguleg & möguleg \\
\hline 3 & kvk & 29 & 4 & HC & já & nei & möguleg & möguleg \\
\hline 4 & kvk & 44 & $4-5$ & chol & nei & jákvæð & örugg & líkleg \\
\hline 5 & kk & 78 & $4-5$ & chol & nei & nei & líkleg & líkleg \\
\hline
\end{tabular}

$\mathrm{HC}=$ lifrarfrumuskaði

chol = gallstíflulifrarskað

Biðtími er tími frá upphafi inntöku og par til einkenni komu fram.

Endurgjöf (rechallenge) er jákvæð ef sama vara er tekin inn síðar og sömu sjúkdómseinkenni koma aftur fram, sbr. skilmerki WHO um orsakatengsl.

\section{Tilfelli 3:}

29 ára gömul heilsuhraust kona kom á bráðamóttöku og hafði verið með gulu og kláða í nokkra daga. Hún hafði fundið fyrir kláða af og til í eitt ár. Konan byrjaði að taka Yasmin (dróspírenón og etinýlestradíól) getnaðarvarnartöflur 6 mánuðum fyrir innlögn en einnig Myoplex próteindrykk. Hún hafði tekið Treo (asetýlsalisýlsýra og koffein) og Íbúkód (íbúprófen og kódein) af og til við höfuðverk og notað Herbalifevörur í fjóra mánuði. Engar rannsóknir studdu aðra lifrarsjúkdóma, par með talda lifrarbólgu vegna sjálfsnæmis. Lifrarsýni: Áberandi bólgubreytingar með blandaðri bólgufrumuíferð með eitilfrumum, plasmafrumum, stöku kyrningum og einnig sáust sums staðar rauðkyrningar. Í einu portalsvæði sást eitilfrumupyrping. Í lobuli sást gallstífla í smæstu gallgöngum. Breytingarnar voru taldar samrýmast bráðri lifrarbólgu með útlit sem helst benti til lyfja- eða efnaorsakaðrar lifrarbólgu eða sjálfsnæmislifrarbólgu.

Konan hætti að nota fæðubótarefni og lyf. Lifrarpróf lækkuðu og voru orðin nánast eðlileg innan priggja mánaða. Hún hefur síðan notað íbúprófen án vandamála.

\section{Tilfelli 4:}

44 ára gömul áður heilsuhraust kona var lögð inn vegna kviðverkja og gulu. Hún byrjaði að taka lyfið Zyban (búprópíon) 20 dögum áður og hafði verið að nota Herbalifevörur í 5-6 mánuði. Hún hætti að taka Herbalife og búprópíon og urðu lifrargildi eðlileg. Nokkrum mánuðum síðar fór hún aftur að taka Herbalifevörur og jafnframt birkiösku. Í kjölfarið fékk hún kláða og hækkun á lifrarprófum á ný. Hætti pá notkun Herbalife en hélt áfram að nota birkiösku. Lifrarpróf lækkuðu hratt og urðu eðlileg eftir um tvo mánuði. Rannsóknir bentu ekki til annarra lifrarkvilla.
Tilfelli 5:

78 ára karlmaður með Alzheimerssjúkdóm og háprýsting reyndist við reglubundið eftirlit með hækkun á lifrarprófum með gallstíflumynd. Lyf: Enalapríl til margra ára. Hafði notað Herbalifevörur í 4-5 mánuði. Hætti að nota Herbalife og enalapríl og lifrarpróf urðu eðlileg.

ANA var jákvætt í lágum títra $(>1: 40<1: 100)$ en blóðvatnspróf fyrir lifrarbólguveirum og ómun voru neikvæð.

Allir sjúklingarnir notuðu fleiri en eina vörutegund frá Herbalife. Tafla I sýnir hvaða Herbalifevörur voru notaðar, upptalningin er ekki tæmandi en teknar eru með pær vörur sem innihalda jurtir.

Tafla II er yfirlit yfir sjúklingana, biðtíma fram að einkennum, tegund lifrarskaða og orsakatengsl sem voru metin með tveimur mismunandi aðferðum, RUCAM og WHO-UMC.

Tafla III sýnir lifrargildi sjúklinga. Í öllum tilvikum voru prótrombín-tími og albúmín eðlileg.

Skoðuð voru fimm tilfelli til viðbótar sem voru sjúklingar með lifrarskaða sem tóku Herbalife, tvö tilfelli á Landspítala, eitt utan spítala og tvær aukaverkanatilkynningar hjá Lyfjastofnun. Pessir fimm sjúklingar voru ekki teknir með í pessari samantekt vegna pess að í öllum tilfellum voru til staðar aðrar vel hugsanlegar

Tafla III. Taflan sýnir hæstu lifrargildi fyrir hvern sjúkling (margfeldi af efri eđlilegum mörkum).

\begin{tabular}{ccccc}
\hline sjúkl. nr. & kyn & $\begin{array}{c}\text { bílirúbínmörk }<20 \\
\mathrm{mmol} / \mathrm{L}\end{array}$ & $\begin{array}{c}\text { ALPmörk 35-105 } \\
\text { U/L }\end{array}$ & $\begin{array}{c}\text { ALTmörk <70 kk, } \\
<45 \mathrm{kvk} \mathrm{U/L}\end{array}$ \\
\hline 1 & $\mathrm{kvk}$ & $311(15,6)$ & $149(1,4)$ & $1134(25,2)$ \\
\hline 2 & $\mathrm{kvk}$ & $190(9,5)$ & $407(3,9)$ & $2600(57,8)$ \\
\hline 3 & $\mathrm{kvk}$ & $247(12,3)$ & $547(5,2)$ & $2487(55,3)$ \\
\hline 4 & $\mathrm{kvk}$ & $64(3,2)$ & $231(2,2)$ & $2637(58,6)$ \\
\hline 5 & $\mathrm{kk}$ & $26(1,3)$ & $712(6,8)$ & $456(6,5)$ \\
\hline
\end{tabular}

$\mathrm{ALP}=$ alkalískur fosfatasi

ALT=alanín amínótransferasi 
skýringar á lifrarskaðanum en Herbalife. Рað er pó ekki útilokað að Herbalife hafi átt pátt 1 lifrarvandamálum einhverra pessara sjúklinga.

\section{Umræða}

Hér er lýst fimm sjúklingum með eitrunarlifrarbólgu sem grunur lék á að mætti rekja til neyslu Herbalife. Ályktun um orsakatengsl við Herbalife byggist á pví að sjúkdómseinkenni komu fram pegar Herbalife hafði verið neytt í nokkurn tíma, einkenni hurfu pegar neyslu Herbalife var hætt og ekki var til staðar önnur sennilegri skýring. Petta styrkist enn frekar af einu tilfelli (nr. 4) par sem endurtekin neysla Herbalife síðar leiddi til sömu eða svipaðra einkenna (positive rechallenge). Mat á orsakasamhengi samkvæmt WHO-UMC í pessu tilfelli var að tengsl við Herbalife væru örugg en samkvæmt RUCAM líkleg, en síðarnefnda flokkunin býður ekki uppá að tengsl séu örugg. Í hinum tilfellunum fjórum voru orsakatengsl ekki eins ákveðin.

Í öllum sjúklingunum voru hækkuð lifrarensím í blóði sem samræmast lifrarskaða. Sama má segja um lifrarsýni sem voru tekin í tveimur sjúklinganna en vefjabreytingar sýndu áberandi bólgubreytingar sem vel geta samræmst eitrunarlifrarbólgu af völdum lyfja eða eiturefna. Pessar rannsóknir sýndu ekki alltaf alveg sömu sjúkdómsmynd og sama er uppi á teningnum í peim tilfellum sem áđur hefur verið lýst en petta gæti skýrst af áverkun mismunandi efna í mismunandi skömmtum eða blöndum ásamt mismunandi ástandi sjúklinganna og hugsanlegum erfðabreytileika. Petta mælir pó alls ekki gegn pví að um orsakasamband sé að ræða.

Sjúklingarnir voru rannsakaðir með venjubundnum hætti með tilliti til annarra mögulegra lifrarsjúkdóma. Í einu tilfelli (nr. 1) var hækkun á kjarnamótefnum sem geta myndast hjá sjúklingum með sjálfsnæmislifrarbólgu og orkukornamótefnum sem sjást hjá sjúklingum með frumkomna gallskorpulifur (primary biliary cirrhosis). Hins vegar lækkuðu pessi mótefni og lifrarpróf urðu eðlileg pegar notkun Herbalife var hætt og klínísk mynd og vefjasýni samrýmdist ekki frumkominni gallskorpulifur. Pekkt er að við eitrunarlifrarbólgu getur komið fram hækkun slíkra mótefna. ${ }^{13}$ Kjarnamótefni voru einnig til staðar í lágum styrk í tilfelli nr. 5 .

Í sumum tilfellum var ekki hægt að útiloka pátt lyfja eða annarra náttúruefna. Í tifelli nr. 2 hafði sjúklingurinn einnig neytt sólhatts sem virðist geta valdið eitrunarlifrarbólgu. ${ }^{10,14}$ Í tifelli nr. 3 var sjúklingur jafnframt að taka getnaðarvarnarlyfið Yasmin (dróspírenón og etinýlestradíól).
Getnaðarvarnarhormón geta valdið lifrarskaða en pá er nánast alltaf um gallstíflumynd að ræða en svo var ekki í pessu tilfelli. Lifrarskaði er ekki pekkt aukaverkun Yasmin (sjá Sérlyfjaskrá). Sami sjúklingur hafði einnig notað asetýlsalisýlsýru og íbúprófen í litlu magni með hléum við tilfallandi höfuðverk. Lifrarskaða hefur verið lýst eftir íbúprófen en sjúklingurinn hóf aftur notkun pess án vandkvæða. Asetýlsalisýlsýra getur einnig valdið lifrarskaða en pá er yfirleitt um stöðuga notkun og hærri skammta að ræða en í pessu tilfelli. $^{15}$

Sjúklingur nr. 5 hafði til margra ára tekið lyfið enalapríl en lifrarskaða hefur verið lýst eftir notkun pess, jafnvel eftir langvarandi notkun. ${ }^{16}$ Petta virðist pó sjaldgæft og tímatengsl við Herbalifenotkun gera pað að líklegri orsök fyrir lifrarskaða hjá pessum sjúklingi.

Birtar hafa verið niðurstöður rannsóknar ${ }^{17}$ par sem lýst er 10 sjúklingum með lifrarskaða sem að líkindum tengjast notkun Herbalife. Einnig hafa verið birtar niðurstöður ísraelskrar rannsóknar par sem lýst er 12 sjúklingum með lifrarskemmdir sem líklega tengjast notkun á Herbalife. ${ }^{18,19}$ Á Spáni var lýst fjórum tilfellum með lifrarskaða í tengslum við notkun Herbalife..$^{20}$ Að lokum birtist grein $^{21}$ par sem lýst er tveimur sjúklingum með lifrarskemmdir af völdum Herbalife sem rakið var til mengunar með Bacillus subtilis. Ef allt er talið saman hafa verið birt 28 tilfelli en líkindin á orsakatengslum við töku Herbalife eru missterk.

Pau fimm tilfelli sem hér er lýst bætast við pau 28 sem áður hafa verið birt. 17, 18, 21, 22 Aðeins er hægt að geta sér til um orsakirnar en líklegast virðist að einhverjar af pessum vörum innihaldi eitraðar jurtir. ${ }^{1}$ раð er athyglisvert að peir sjúklingar sem hér er sagt frá voru flestir að taka sömu vörur frá Herbalife en sumar peirra innihalda einmitt jurtir sem vitað er að geta valdið lifrarskemmdum; RoseOx og Herbalifeline innihalda negul en í honum er evgenól sem getur valdið lifrarskemmdum á svipaðan hátt og parasetamól ${ }^{23}$ og Thermojetics inniheldur útdrátt (extract) úr grænu tei sem einnig getur valdið lifrarskemmdum. ${ }^{5}$ Parna kunna að leynast fleiri eitraðar jurtir vegna pess að innihaldslýsingar eru ekki alltaf fullkomnar og eiturefnafræði jurta er iðulega vanrannsökuð. Vandamál af pessum toga eru alls ekki bundin við vörur frá Herbalife og nýlega var talsverð fjölmiðlaumræða um megrunarvöruna LipoKinetix ${ }^{24}$ og Hydroxycut ${ }^{25}$ sem var auglýst til vaxtarræktar og megrunar en LipoKinetix og sumar vörur af merkinu Hydroxycut voru teknar af markaði vegna fjölda tilfella af eitrunarlifrarbólgu.

Segja má að pau sjúkdómstilfelli sem hér 
hefur verið lýst hafi fundist fyrir tilviljun enda eru skráningarkerfi sjúkdóma (ICD-9 og ICD-10) ekki vel til pess fallin að leita uppi aukaverkanir af völdum náttúruefna. Einnig má benda á að fullt samræmi er ekki alltaf til staðar við sjúkdómsgreiningar. Faraldsfræðilegt gildi pessarar rannsóknar er pví mjög takmarkað. Vel er mögulegt að lifrarskaði vegna náttúruefna sé mun algengari en pessi samantekt gefur til kynna, eitthvað sé af innlögnum á heilbrigðisstofnanir sem höfundar hafa ekki vitneskju um og eitthvað gæti líka verið um vægari tilfelli sem ekki leiða til innlagnar. Pessir fimm sjúklingar náðu allir heilsu eftir að töku Herbalife var hætt og vonandi verða engin eftirköst en síðkominni bandvefsmyndun í lifur hefur verið lýst. ${ }^{17}$ Af peim 28 sjúklingum sem lýst var í Sviss, Ísrael og Spáni fengu fjórir bráđa lifrarbilun, tveir fóru í lifrarígræðslu og einn dó eftir slíka aðgerð. Ekki liggja fyrir tölur um fjölda peirra sem nota vörur frá Herbalife hér á landi en telja má víst að peir séu margir og aukaverkanir af pví tagi sem hér er lýst par af leiðandi sjaldgæfar.

Sú spurning hlýtur að vakna hvort einhverjir skilgreinanlegir hópar fólks séu í meiri hættu en aðrir að fá aukaverkanir af pessu tagi. Ekki hefur tekist að koma auga á slíkt í peim greinum sem hafa birst, sjúklingarnir eru ekki tiltakanlega feitir (BMI á bilinu 22-35; n=19) og ekki með undirliggjandi lifrarsjúkdóm eftir pví sem næst verður komist. Eftir stendur möguleikinn á pví að pessir sjúklingar hafi verið með einhvern óskilgreindan erfðabreytileika sem gerði pá viðkvæmari en aðra fyrir viðkomandi efnum en slíkt eru enn sem komið er einungis vangaveltur. Рað er pekkt staðreynd að fyrri saga um lifrarskaða vegna lyfja eykur líkurnar á lifrarskaða af völdum annarra lyfja eða efna og í pessari samantekt á tilfellum var reyndar einn sjúklingur með fyrri sögu um lifrarskaða eftir töku Primazol (tilfelli 2). Ekki er heldur vitað hvort vörurnar frá Herbalife voru í öllum tilvikum teknar í ráðlögðum skömmtum.

Telja má nokkuð víst að langflestar náttúruvörur sem hér eru á markaði séu meinlausar og sumar peirra gætu gert eitthvert gagn, pó að yfirleitt hafi ekki verið sýnt fram á slíkt með vísindalegum aðferðum. Petta gildir eflaust líka um vörur frá Herbalife sem flestar eru í raun venjuleg matvara. Frá pessu eru pó margar undantekningar par sem um er að ræða vörur með ýmiss konar jurtum sem mismikið er vitað um. Раð er athyglisvert að af peim tilfellum sem hér hefur verið fjallað um voru einungis tvö tilkynnt til Lyfjastofnunar en í erlendum faraldsfræðilegum rannsóknum á lifrarskaða vegna lyfja eða náttúruefna hefur hlutfall náttúruefna verið $2-10 \%{ }^{26,27}$
Раð hlýtur að teljast alvarlegt mál ef vörur sem eiga að bæta heilsufar hafa alvarlegar aukaverkanir, jafnvel pó pað sé í litlum mæli. Nokkrar umræður hafa orðið um algengi aukaverkana frá lifur við neyslu Herbalife og hafa fulltrúar fyrirtækisins reynt að gera lítið úr hættunni. ${ }^{28}$ Hins vegar hefur verið á pað bent að skráningu aukaverkana náttúruefna er víðast hvar mjög ábótavant og kannski höfum við bara séð topp ísjakans. Ekki liggja fyrir upplýsingar um pað magn náttúru- og fæðubótarefna sem neytt er hér á landi og ef til vill pyrfti að efla eftirlit með pessum vöruflokki.

Ályktun: Telja verður líklegt að notkun á Herbalifevörum tengist eitrunarlifrarbólgu. Eitrunarlifrarbólga af völdum náttúruefna er mikilvæg mismunagreining hjá sjúklingum með lifrarskaða. Líkt og með skráð lyf er notkun náttúruefna mikilvæg pegar tekin er sjúkrasaga hjá sjúklingum með lifrarskaða. Tilkynna ber hugsanlegar aukaverkanir af völdum náttúruefna til Lyfjastofnunar eða Matvælastofnunar.

\section{Heimildir}

1. Seeff LB. Are herbals as safe as their advocates believe? J Hepatol 2009; 50: 13-6.

2. Stickel F, Egerer G, Seitz HK. Hepatotoxicity of botanicals. Public Health Nutr 2000; 3: 113-24

3. Stickel F, Patsenker E, Schuppan D. Herbal hepatotoxicity. J Hepatol 2005; 43: 901-10

4. Bottenberg MM, Wall GC, Harvey RL, Habib S. Oral aloe vera-induced hepatitis. Ann Pharmacother 2007; 41: 1740-3.

5. Galati G, Lin A, Sultan AM, O'Brien PJ. Cellular and in vivo hepatotoxicity caused by green tea phenolic acids and catechins. Free Radic Biol Med 2006; 40: 570-80.

6. Molinari M, Watt KD, Kruszyna T, et al. Acute liver failure induced by green tea extracts: case report and review of the literature. Liver Transpl 2006; 12: 1892-5.

7. Bjornsson E, Olsson R. Serious adverse liver reactions associated with herbal weight-loss supplements. J Hepatol 2007; 47: 295-7; author reply 297-8.

8. De Smet PA. Herbal remedies. N Engl J Med 2002; 347: 204656

9. De Smet PA. Health risks of herbal remedies: an update. Clin Pharmacol Ther 2004; 76: 1-17.

10. Pórhallsdóttir Ó, Ingólfsdóttir K, Jóhannsson M. Aukaverkanir og milliverkanir náttúrulyfja, náttúruvara og fæðubótarefna. Læknablaðið 2002; 88: 289-97.

11. Danan G, Benichou C. Causality assessment of adverse reactions to drugs--I. A novel method based on the conclusions of international consensus meetings: application to drug-induced liver injuries. J Clin Epidemiol 1993; 46: 1323-30.

12. UMC-WHO. Causality Assessment of Suspected Adverse Reactions. www.who-umc.org/DynPage.aspx?id=22682. 2009

13. Dansette PM, Bonierbale E, Minoletti C, et al. Drug-induced immunotoxicity. Eur J Drug Metab Pharmacokinet 1998; 23: 443-51.

14. Jacobsson I, Jonsson AK, Gerden B, Hagg S. Spontaneously reported adverse reactions in association with complementary and alternative medicine substances in Sweden. Pharmacoepidemiol Drug Saf 2009. In print.

15. Zimmerman HJ. Effects of aspirin and acetaminophen on the liver. Arch Intern Med 1981; 141: 333-42.

16. Macias FM, Campos FR, Salguero TP, et al. Ductopenic hepatitis related to Enalapril. J Hepatol 2003; 39: 1091-2.

17. Schoepfer AM, Engel A, Fattinger K, et al. Herbal does not mean innocuous: ten cases of severe hepatotoxicity associated with dietary supplements from Herbalife products. J Hepatol 2007; 47: 521-6. 
18. Elinav E, Pinsker G, Safadi $R$, et al. Association between consumption of Herbalife nutritional supplements and acute hepatotoxicity. J Hepatol 2007; 47: 514-20.

19. Stickel F. Slimming at all costs: Herbalife-induced liver injury. J Hepatol 2007; 47: 444-6.

20. Duque JM, Ferreiro J, Salgueiro E, Manso G. [Hepatotoxicity associated with the consumption of herbal slimming products]. Med Clin (Barc) 2007; 128: 238-9.

21. Stickel F, Droz S, Patsenker E, et al. Severe hepatotoxicity following ingestion of Herbalife nutritional supplements contaminated with Bacillus subtilis. J Hepatol 2009; 50: 111-7.

22. Manso G, Lopez-Rivas L, Duque JM, Salgueiro E. Spanish reports of hepatotoxicity associated with Herbalife products. J Hepatol 2008; 49: 289-90; author reply 290-1.

23. Janes SE, Price CS, Thomas D. Essential oil poisoning $\mathrm{N}$-acetylcysteine for eugenol-induced hepatic failure and analysis of a national database. Eur J Pediatr 2005; 164: 520-2.

24. Guo L, Shi Q, Fang JL, et al. Review of usnic acid and Usnea barbata toxicity. J Environ Sci Health C Environ Carcinog Ecotoxicol Rev 2008; 26: 317-38.
25. Dara L, Hewett J, Lim JK. Hydroxycut hepatotoxicity: a case series and review of liver toxicity from herbal weight loss supplements. World J Gastroenterol 2008; 14: 6999-7004.

26. Andrade RJ, Lucena MI, Fernandez MC, et al. Drug-induced liver injury: an analysis of 461 incidences submitted to the Spanish registry over a 10 -year period. Gastroenterology 2005; 129: 512-21.

27. Ibanez L, Perez E, Vidal X, Laporte JR. Prospective surveillance of acute serious liver disease unrelated to infectious, obstructive, or metabolic diseases: epidemiological and clinical features, and exposure to drugs. J Hepatol 2002; 37: 592-600.

28. Ignarro L, Heber D, Henig YS, Bejar E. Herbalife nutritional products and liver injury revisited. J Hepatol 2008; 49: 291-3; author reply 293-4.

\section{Hepatotoxicity associated with the use of Herbalife}

Objective: Many herbal products are known to be hepatotoxic. In a recent survey in Iceland concerning adverse reactions related to herbal medicines, Herbalife products were implicated in the majority of the reported cases of hepatotoxicity.

Methods: The clinical presentations of five cases of Herbalife related liver injury during the period of 1999-2008 are analysed. Causality was assessed by using the WHOUMC system for causality assessment and the RUCAM method.

Results: Of the five cases there were four females and one male; median age was 46 years (range 29-78). Herbalife had been used for 1 to 7 months prior to presentation. Four patients presented with a hepatocellular and one with a cholestatic reaction. Median values were for bilirubin $190 \mu \mathrm{mol} / \mathrm{L}$ (range: 26-311; ref. < $20 \mu \mathrm{mol} / \mathrm{L}$ ),
ALP 407 U/L (range: 149-712; ref. 35-105 U/L) and ALT $2487 \mathrm{U} / \mathrm{L}$ (range: 456-2637; ref. 70 and $45 \mathrm{U} / \mathrm{L}$ for males and females, respectively). Liver biopsy was performed in 2 patients and was consistent with toxic hepatitis in both cases. Other causes of hepatitis were excluded by appropriate serological testing and ultrasound. Causality assessment according to RUCAM was probable in three cases and possible in two. Using the WHO-UMC criteria causality was certain in one case, probable in two and possible in two cases.

Conclusions: Hepatotoxicity is probably associated with the use of Herbalife products. Hepatotoxicity due to herbal remedies is an important differential diagnosis in the diagnostic work-up of liver injury.

Johannsson M, Ormarsdottir S, Olafsson S

Hepatotoxicity associated with the use of Herbalife. Icel Med J 2010; 96: 177-82

Key words: toxic hepatitis, herbal remedies, Herbalife.

Correspondence: Magnús Jóhannsson, magjoh@hi.is 